як навчальної дисципліни у контексті сучасної вітчизняної освіти / А. Ю. Свириденко // Матеріали Міжнар. наук.-практ. конф. «Ідеї К. Д. Ушинського в сучасній педагогіці» (м. Київ, 2014 р.). - С. 112-117. 11. Семенець Л. М. Формування професійної готовності майбутніх учителів до розвитку математичних здібностей у старшокласників: дис. на здобуття наук. ступеня канд. пед. наук : 13.00.04 / Семенець Лариса Миколаївна. - Житомир, 2013. -247 с. 12. Старіш О. Г. Системологія: [підручник] / Олександр Григорович Старіш. - Київ : ЦНЛ, 2005. - 232 с. 13. Талызина Н. Ф. Управление процессом усвоения знаний / Н. Ф. Талызина. М. : МГУ, 1975. - 343 с. 14. Штофф В. А. Моделирование и философия : [монография] / Виктор Александрович Штофф. - Москва - Ленинград : Наука, 1966. - 303 с.

УДК 373.51 .78

Віталій Смородський

\title{
ОРГАНІЗАЦІЙНО-ПЕДАГОГІЧНІ УМОВИ ФОРМУВАННЯ ВИКОНАВСЬКИХ НАВИЧОК НА ЗАСАДАХ ЖАНРОВОГО ПІДХОДУ В УЧНІВ ДИТЯЧИХ МУЗИЧНИХ ШКІЛ
}

Смородський В. I. Організаційно-педагогічні умови формування виконавських навичок на засадах жанрового підходу в учнів дитячих музичних шкіл.

У статті проаналізовано та розкрито методологічну сутність понять «педагогічні умови» та «організаційно-педагогічні умови». Визначено педагогічні умови формування виконавських навичок учнів дитячих музичних шкіл на основі жанрового підходу: формування мотиваційної спрямованості процесу навчання з оволодіння виконавськими навичками на основі жанрового підходу; вибір змісту, форми, методів та засобів формування виконавських навичок на основі жанрового підходу; налагодження діалогічного спілкування викладача та учня як основи формування виконавських навичок на основі жанрового підходу.

Ключові слова: виконавські навички, жанровий підхід у формуванні виконавських навичок в учнів дитячих музичних шкіл, педагогічні умови.

Смородский В. И. Организационно-педагогические условия формирования у учеников детских музыкальных школ исполнительских навыков на основе жанрового подхода.

В статье проанализирована и раскрыта методологическая суть понятий «педагогические условия» и «организационно-педагогические условия». Определены педагогические условия формирования исполнительских навыков учащихся детских музыкальных школ на основе жанрового подхода: формирование мотивационной направленности процесса обучения по овладению исполнительскими навыками на основе жанрового подхода; выбор содержания, форм, методов и средств формирования исполнительских навыков на основе жанрового подхода; налаживания диалогического общения преподавателя и ученика как основы формирования исполнительских навыков на основе жанрового подхода.

Ключевые слова: исполнительские навыки, жанровый подход в формировании исполнительских навыков у учащихся детских музыкальных школ, педагогические условия.

Smorodskyi V. I. Organizational and pedagogical conditions of performance skills formation of music schools pupils on the basis of genre approach.

In the article methodological meaning of the term «Pedagogical conditions» was analysed. 
Pedagogical conditions of performance skills formation of music schools pupils on the basis of genre approach were difined. They are the formation of motivational direction of teaching process for mastering performance skills on the basis of genre approach; choice of content, forms, methods and means of performance skills formation on the basis of genre approach; building of dialogic communication between a teacher and a pupil as bases of performance skills formation on the basis of genre approach.

Key words: performance skills, genre approach in performance skills formation at music schools pupils, pedagogical condition.

Найголовнішу роль у формуванні сучасних основ музичної культури учнів, безумовно, відіграє школа. Саме тут виховується естетичне ставлення майбутньої людини до навколишнього світу, формуються якості та властивості особи, що спрямовують i координують ї̈ подальший розвиток. Школа та шкільна естетика побуту покликані відкрити перед кожним учнем шлях до пізнання прекрасного, навчити цінувати і розуміти його. Уроки музичного мистецтва, так само, як, скажімо, уроки літератури або образотворчого мистецтва, мають бути справжньою школою мистецтва, що дає молоді художній багаж на все життя.

Складність поняття музичного жанру пов’язана з безліччю чинників: формою та місцем виконання, виконавськими засобами, характером змісту, життєвим призначенням, умовами та формами існування, особливостями музичної мови, - тому, розглядаючи кожен окремий твір у цих площинах, ми можемо віднести його одразу до кількох жанрів. Проте, попри всі існуючі умовності жанрових меж, попри складність та багатозначність самого поняття, жанрові ознаки залишаються відносно стійкими та слугують свідченням не «заплутаності» музичної науки, а багатством музичного мистецтва.

Питання набуття виконавських навичок у різних галузях вивчали такі науковці, як Л. Беспалова, А. Богуш, С. Воробйова, Н. Головіна, І. Гудзик, А. Маркова, Т. Рахімов, О. Трифонова, Ю. Шапран та інші. Взаємозв’язок виконавських навичок і компетентностей висвітлено у працях вітчизняних та зарубіжних науковців - Н. Бібік, Л. Ващенка, Л. Паращенко, Д. Равена, О. Савченко, А. Хуторського тощо. Аналіз деяких робіт з проблеми компетентності (В. Байденко, Г. Беліцька, Л. Берестова, Н. Грішанова, Н. Кузьміна, В. Куніцина, А. Марков, Дж. Рівний, Р. Уайт, Н. Хомський, А. Хуторський та ін.) дозволяє сформувати таке поняття «компетенції», яке найбільш чітко характеризує цей термін у галузі музичної освіти: компетенція (від. лат. Competencia - коло питань, з якими людина добре обізнана, володіє знаннями і досвідом) - це інтегрований результат опанування змістом освіти, який виражається в готовності учня використовувати засвоєні знання, уміння, навички, а також засоби діяльності в конкретних життєвих ситуаціях для розв'язання практичних і теоретичних задач.

Важливе значення у процесі навчання учнів дитячих музичних шкіл має правильне формування у них стильових i жанрових навичок оволодіння музичним матеріалом. Музичний жанр - багатозначне поняття, що характеризує історично сформовані роди і види музичних творів у зв'язку з їх походженням і життєвим призначенням, способом та умовами виконання і сприйняття, а також з особливостями змісту і форми. Аналіз наукової літератури показує, що феномен жанру в музичній теорії та історії розвитку мистецтв багатосторонній. 3 позиції нашого дослідження необхідно звернути увагу на використання жанрового підходу й у лінгвістиці. Тим часом, жанрова парадигма, як музично-педагогічний і методологічний принцип, містить і певний перелік принципів та технологій. Серед них ми актуалізуємо саме інтегративні технології як необхідну частину жанрової парадигми у процесі навчання 
гри на фортепіано.

Поняття музичного жанру відображає основну проблему музикознавства та музичної естетики - взаємозв’язок між факторами творчості, не пов’язаними з музикою, та ії суто музичними характеристиками. Музичний жанр $€$ одним з найважливіших засобів художнього ототожнення. Проведені дослідження довели можливість використання жанрової парадигми як необхідної підстави для навчання грі на фортепіано учнів ДМШ, яка сприяє формуванню їх художнього світогляду, що дозволяє вийти за межі завдань виключно технічного виконавства. Ми вважаємо, що така спрямованість освітнього процесу більш важлива для подальшого життєвого шляху дитини в сучасному соціокультурному просторі. Жанрова парадигма грунтується на визначених музикознавчих аспектах, які представлені в працях А. Коробової, Є. Назайкинського, А. Сохора, Т. Чередниченко та ін. У працях науковців досліджується історична еволюція музичних жанрів, їх різновиди, зв’язок з культурними зрізами тощо. Жанри існують відповідно $з$ різними видами музики, її стилів, і навіть видів музикування.

У музичній науці склалися різні системи класифікації жанрів. Вони залежать від того, який з чинників, що обумовлює жанр, розглядається як основний. Наприклад, В. Цуккерман визначає пріоритетним чинник змісту (жанр- типізований зміст), А. Сохор- фактор життєвого призначення музики та обстановки іï виконання та сприйняття. Також поняття музичного жанру з різних аспектів розглядали такі науковці, як Л. Мазель, Е. Назайкинський, Т. Попова, В. Холопова та ін.

3 позиції нашого дослідження доречно визначити поняття «організаційно-педагогічні умови» як сукупність об'єктивних можливостей, обставин та заходів, що супроводжують освітній процес, певним чином структурованих і спрямованих на досягнення найкращих результатів поставленої мети (К. Бабанський, В. Звєрев, В. Краєвський, В. Ледньов, В. Ляудіс). Аналіз поняття «умова» у філософському аспекті: умова - сукупність об’єктів (речей, процесів, відносин), що необхідні для виникнення, існування або зміни певного об'єкта [8, с. 286]. У педагогічній літературі відсутнє єдине трактування поняття «педагогічна умова». В. Стасюк визначає педагогічні умови як обставини, від яких залежить та в яких відбувається цілісний педагогічний процес професійної підготовки фахівців, що опосередковується активністю особистості, групою людей [6, с. 98]. У словнику з освіти та педагогіки «умова» визначається як сукупність змінних природних, соціальних, зовнішніх та внутрішніх впливів на фізичний, психічний, моральний розвиток людини, його поведінку, виховання і навчання, формування особистості [7, с. 36]. Дослідники приділяють багато уваги вивченню педагогічних умов та надають вагомого значення їх впливу на навчальний процес. Так, наприклад, Ю. Бабанський зазначав, що «ефективність педагогічного процесу закономірно залежить від умов, у яких він проходить» [1, с. 78]. Аналіз теоретичних засад жанрового підходу в нашому дослідженні дозволили встановити основні організаційно-педагогічні умови формування виконавських навичок на засадах жанрового підходу в учнів дитячих музичних шкіл.

Розглянемо їх більш детально. До першої організаційно-педагогічної умови ми віднесли формування мотиваційної спрямованості процесу навчання на опанування жанрового підходу. В. Зіборова зазначає, що формування мотивації є важливим процесом реалізації жанрового підходу, що необхідно для повноцінного розвитку особистості. Створення професійно орієнтованих завдань, педагогічних ситуацій на заняттях допомогає у створенні мотивації оволодінням жанровим підходом [4]. Я. Карлінська звертає увагу на важливість формування позитивної мотивації самостійного навчання; створення сприятливої емоційної атмосфери на заняттях, налагодження партнерської взаємодії ... у процесі 
навчання [5, с. 170]. Мотивація спонукає особу розвивати свої схильності, можливості, здійснює вплив на формування особистості учнів та розкриття їх творчого потенціалу.

Основи жанрового підходу повинні бути закладені шляхом установлення органічного зв’язку між теорією і практикою, шляхом навчання їх практичного використання, аналізу конкретних прикладів, розв'язання конкретних проблемних питань. Знання повинні бути актуалізовані й об'єднані навколо певного проблемного твору, мати багатобічний й цілісний характер та переведені на мову практичних дій.

Друга педагогічна умова - вибір змісту, форм, методів і засобів формування виконавських навичок на засадах жанрового підходу полягає у створенні навчальнометодичних матеріалів, якими педагог зможе керувати та брати на себе відповідальність за структуру, оновлення та впровадження в навчальний процес для розвитку особистості школяра.

Формування виконавських навичок на засадах жанрового підходу полягає в забезпеченні збалансованості між індивідуальними та груповими формами навчання. Використання групових методів навчання допомагає найбільш продуктивно формувати уміння проектувати, конструювати професійні задачі, навчатися професійній рефлексії. За спостереженням Н. Шевардіна, застосування групових методів та форм проведення занять, що імітують або відтворюють творчу діяльність учнів, пов’язану з їх інтересами «шляхом реалізації принципу адекватності навчально-пізнавальної діяльності, сприяють активізації навчання у групі» [2]. Налагодження діалогічного спілкування педагога та учня як основи формування виконавських навичок на засадах жанрового підходу $\epsilon$ третьою педагогічною умовою.

Найкращим засобом досягнення високого рівня співробітництва та взаєморозуміння у спілкуванні є діалог. На думку Н. Волкової, педагогічний діалог- це дія в педагогічному процесі, яка надає змогу кожному партнерові самовиразитись у спілкуванні. Педагогічний діалог характеризують відвертість, гуманність, толерантність, доброзичливість, спільне бачення суб’єктами взаємодії ситуації, взаємна спрямованість на розв’язання проблеми, активність, за якої кожен не лише відчуває вплив, а й сам впливає на іншого співрозмовника, готовність прийняти точку зору іншого, рівність психологічних позицій викладача i студента, взаєморозуміння, проникнення у світ один одного. Переорієнтація викладача від передачі готових знань до виконання ролі консультанта, керівника, який опосередковано організує та стимулює учасників навчальної діяльності, надає ширші можливості для власної самоактуалізації та розвитку.

Викладач має активно брати участь у навчальному процесі, коментуючи та коректуючи поточну роботу учасників навчальної діяльності- учнів дитячої музичної школи. Головною вимогою в організації навчального процесу є посилення самостійності в навчанні учнів. Це досягається шляхом ускладнення вимог до змісту та форм самостійної роботи, прилучення учнів дитячих музичних шкіл до самоорганізації в навчанні, переведенням умінь на рівень елементів самоосвіти та самовдосконалення.

Відповідна організаційно-педагогічна умова формування виконавських навичок на засадах жанрового підходу в учнів дитячих музичних шкіл дозволяє виявити особливості навчальної діяльності у ДМШ, які часто бувають не поміченими. Так, більшість навчальних програм містять одноманітні перевірки системи знань (чітка доповідь за пропонованим питанням, творче розв’язання задачі, технічна робота за аналогом тощо). Використання однобічності методів не дозволяє розкрити повний потенціал учнів, значна кількість яких $є$ творчими особистостями. Використання творчих, інтерактивних, ігрових методів навчання 
необхідно максимально наблизити до повноцінного засвоєння навчального матеріалу. Наші дослідження показали, що активне застосування творчого підходу до занять формують в учнів неабиякий інтерес та сприяють запам’ятовуванню й відтворенню матеріалу. Контроль якості навчання показує кращий результат.

Слід зазначити, що ефективним шляхом оновлення освіти $\epsilon$ інтеграція як сучасна форма організації наповнення освіти на основі взаємозв’язку та єдності законів природи, цілісності людини і цілісності сприйняття суб’єктом навколишнього світу. Отже, інтегративний підхід розглядається нами як необхідна умова гармонізації взаємин людини з навколишнім світом. Він стає фактором, який поєднує різні явища у процесі їх безперервної взаємодії: суб’єктивні й об’єктивні, внутрішні й зовнішні, раціональні та емоційні, свідомі й підсвідомі; нормативні та творчі тощо. Останнім часом в освітньому просторі України у процесі художнього виховання школярів визначилась тенденція практичного застосування художньої інтеграції.

Отже, складність процесу формування виконавських навичок в учнів дитячих музичних шкіл на засадах жанрового підходу залежить від багатьох чинників, що вимагає реалізації комплексу організаційно-педагогічних умов, тобто такої сукупності, у якій кожна умова $є$ основою для наступної. Дієвість педагогічних умов формування виконавських навичок на засадах жанрового підходу в учнів дитячих музичних шкіл визначається їх здатністю творчо застосовувати отримані знання в нестандартних ситуаціях; здобувати, використовувати, творчо їх переосмислювати.

\section{Література}

1. Бабанский Ю. К. Оптимизация учебно-воспитательного процесса / Ю. К. Бабанский. - Москва : Просвещение, 1982. - 192 с. 2. Болюбаш Н. М. Фактори та умови формування професійної компетентності майбутніх економістів засобами інформаційного середовища Moodle [Електронний ресурс] / Н. М. Болюбаш // Інформаційні технології і засоби навчання. - 2010. - №3 (17). - Режим доступу: http://www.nbuv.gov.ua/ejournals/ITZN/em17/content/10bnmtno.htm. 3. Зіборова В. В. Формування інформаційної компетентності викладача [Електронний ресурс] / В. Зіборова // Вісник ЛНУ імені Тараса Шевченка. - 2010. - № 8. - (195). - С. 64-67. - Режим доступу : http://www.nbuv.gov.ua/ portal/Soc_Gum/Vlush/Ped/2010_8/14.pdf. 4. Карлінська Я. В. Педагогічні умови формування інформаційної компетентності студентів у процесі навчання природничо-математичних дисциплін [Електронний ресурс] / Я.В.Карлінська // Вісник Житомирського державного університету. Випуск 53. Педагогічні науки. - С. 169-175. - Режим доступу: httр:// www.nbuv.gov.ua/portal/Soc_Gum/VZhDU/2010_53/vip_53_33.pdf. 5. Стасюк В. Д. Особистісноорієнтовані відносини як педагогічна умова вдосконалення професійної підготовки / В. Д. Стасюк / матеріали міжвузівської науково-практичної конференції «Шляхи удосконалення підготовки військових фахівців та формування професійних якостей».Одеса : ОІСВ, 2003. -107 с. 6. Полонский В. М. Словарь по образованию и педагогике / В. М. Полонский. - Москва : Высш. шк., 2004. - 512 с. 7. Философская энциклопедия : В 5 т. / [науч. ред. Ф. В. Константинов]. - Москва : Советская энциклопедия, 1964. - Т. 5. 1964. - 740 c. 
